\title{
COVID-19 Treatment and Post-COVID-19 Complication Syndrome: A Review
}

\section{SM Rathnasiri Bandara ${ }^{*}$, S Samita ${ }^{2}$, Terrence Madhujith $^{3}$ SS Hettiarachchi $^{4}$ and SMTN Senanayaka ${ }^{5}$}

${ }^{1}$ Senier Medical Officer and an Inverter, Department of Outpatient Department, Teaching Hospital Peradeniya, Sri Lanka

${ }^{2}$ Senior Professor Department of Crop Science, Professor of Statistics, Faculty of Agriculture, University of Peradeniya, Sri Lanka

${ }^{3}$ Professor of Food Science and Technology \& Department Chair, Department of Food Science and Technology, Faculty of Agriculture, University of Peradeniya, Peradeniya, Sri Lanka

${ }^{4}$ M.Sc. in Nanoscience and Nanotechnology by Coursework, Former Teaching Assistants, Department of Chemistry, Faculty of Science, University of Peradeniya, Sri Lanka

${ }^{5}$ Medical Students, Faculty of Medicine, University of Ruhuna, Sri Lanka

*Corresponding Author: SM Rathnasiri Bandara, Senier Medical Officer and an Inverter, Department of Outpatient Department, Teaching Hospital Peradeniya, Sri Lanka.
Received: March 30, 2020

Published: April 24, 2020

(C) All rights are reserved by SM Rathnasiri

Bandara., et al.

\begin{abstract}
The novel coronavirus disease 2019 caused by the SARS-Cov-2 virus belonging to the coronaviridae family to which SARS-CoV and, MERS-CoV belonged. Therefore viral immunopathology and treatment plane of COVID-19 have been explained based mainly on SARS-Co V 2 as well as the known similar viral immunopathology to SARS. The major pathogenic mechanisms of COVID-19 include excesses activation of chemokines and cytokines, deficiencies in the innate immune response, direct involvement of immune cells, direct viral cytopathic effects, down-regulation of lung-protective angiotensin-converting enzyme 2 (ACE2) receptor , autoimmune pathology and genetic factors. The key factors seem that both abnormal immune responses and injury to immune cells increase in the production of inflammatory cytokines, autoantibodies and complement proteins leading to tissue damage. For these possible and obvious immunes - mediated life-threatening complications of viral infection, antiviral drugs, interferon and Cytokine blocking drugs have been used in standard protocol against the COVID-19 immunopathology. It seems to have a lack of efficacy of the drugs due to the inability to stop all vulnerable steps of the immune pathology of the disease. Therefore there is still no recognized or recommended or standard immune regulative treatment plan for COVID 19. Thus, considerations of all these backgrounds, " $5 \mathrm{~S}$ and 5T" to the battle against COVID -19 approach including new corticosteroids protocol for COVID -19 and has been introduced targeting to stop or suppress life-threatening immune pathology of SARS - 2 infection. It is also included the other alternative methods practiced by general community and traditional indigenous approaches. Especially the steroids protocol has been planned in the review with deeply considering avoiding the experience of unsuccessful approaches that caused many harmful effects such as high motility, viremia, increased viral load, no effect, side effect, fungal illness, hyperglycemia, and secondary infections. This review has been considered and described immunological changes in each phase of viral illness and the effective steroid protocol to manage at the pre-preliminary phase, early phase, and middle phase, severe/critical phase and post-viral infected phase .The latter is named as post COVID19 complication syndrome. This new protocol that is open to change and alteration is proposed.

Keywords: COVID-19; SARS-2; Corticosteroids Protocol; Viral Immunopathology
\end{abstract}

\section{Abbreviations}

WHO: World Health Organization; ARDS; Acute Respiratory Distress Syndrome; DSS: Dengue Shock Syndrome; DHF: Dengue Hemorrhagic Fever; CSs: Corticosteroids; IV: Intravenous; MP: Methylprednisolone; HC: Hydrocortisone; ACE2: Angiotensin-Converting
Enzyme 2; AIM2: Absent in Melanoma 2; ASC: Apoptosis-Associated Speck-Like Protein Containing a Caspase Recruitment Domain; BAC: Bacterial Artificial Chromosome; MERS-CoV: Middle East Respiratory Syndrome Coronavirus; RNAi: RNA Interference; SARSCoV: Severe Acute Respiratory Syndrome Coronavirus; CVD: Cardio Vascular Diseases; HAT: Human Airway Trypsin-Like Protease 


\section{Introduction}

The disease caused by SARS-CoV-2, commonly known as novel coronavirus disease (COVID-19) is fast spreading the entire globe. The ongoing outbreak of COVID-19 has been drowning life-saving global attention that initially aroused in the Chinese city of Wuhan (Hubei province) [1] and its alarmingly quick transmission to many other countries across the world resulted in the World Health Organization (WHO) declaring a global health emergency on 30 January 2020 and COVID-19 pandemic [2-5]. The coronavirus COVID-19 is affecting 201 countries and territories around the world and causing the 3,394,195 infected patients, 239,284recovered from illness and 37,578 deaths on 01/05/2020 [6]. Though all deaths and morbidity in viral diseases are caused by excessive and deregulated immune pathology. WHO has recommended not to be used the most important immune-modulating CSs drugs for COVID-19 management. The research findings of dengue and steroids that led to the WHO recommendation of not using CSs for dengue have critically on evidence base medicine by three review articles recently [8-10]. Early phase treatment with corticosteroids in the management of COVID 19 is not recommended due to evidence of mainly one research findings $[11,12]$ and it may be due to past history of unfavorable research conclusions towards CSs as well. The conclusion of the research that gives the administration of CSs in the early phase leading to increase viral load is highly debatable because of a lack of consideration of the therapeutic window of CSs [12]. If CSs can ameliorate the inflammation-induced early phase of disease pathology and stop the replication of the virus in the human body it will give many benefits in the engagement in COVID-19 as in proposed dengue management [8-10]. Clinical application of inhibitory action of viral replication is a main advantage of CSs in this regard like in proposed dengue treatment [8-10]. Thus, it can be hypothesized that administration of CSs or broad spectrums recommended non steroids anti-inflammatory drug at early phase would stop the death and comorbidity of COVID 19 by halting initial and ongoing sever immune pathology.

The reviews are proposed that CSs can be used within a therapeutic window in early phase of COVID -19 so that patients get benefits effects and avoid known harmful effects [13,14]. Moreover, no action or side effects of CSs in dengue treatment concluded were explained on evidence-based medicine. On the other hand same medical and traditional treatments that are discussed here whether their ingredients have befits effects to overcome COVID-19 immune dysfunctions have been already clinically practiced in the community without an especial recommendation.

Finally, this review has been explained a therapeutic window within which CSs can help in many ways to control over activity immunological mechanism of COVID-19 and led to overcome the virus-induced disease pathology that is more or less similar to proposed dengue management except ARDS pathology [8]. On that based, "4S and 4T" to the battle against COVID-19 approach including new corticosteroids protocol for COVID-19 has been explained for COVID-19 management under five phases such as the pre-preliminary phase, early phase, middle phase, sever/critical phase of COVID 19 and post COVID 19 phase.

\section{Evidence to use corticosteroid in early phase COVID-19}

The international guideline that recommends not to use CSs in the early phase of COVID-19 been supported by an evidence of an early phase research of SARS conducted by Nelson Lee and coworkers $[11,12]$. They concluded "early" corticosteroid treatment was associated with a higher subsequent plasma viral load. The findings and observation of the research can be discussed where there are other more important and medically worth information or observation apart from their conclusion.

Only one early phase study was published by them to evaluate the effects of early administration of CSs in the treatment for RSVs/SARS-CoV RNA infection. Lee $\mathrm{N}$ and his collogue conducted the study using hydrocortisone $100 \mathrm{mg}$ every eight hourly/day 3 - 4 days after fever onset that was continued for 7 days [12]. Altogether 17 patients have been recruited to the study. Out of them, one has died and therefore that patient has not been studied. According to the article, out of those 16 patients considered for the analysis, 9 have been selected to the hydrocortisone treated group and the rest to the placebo group. Out of those who received hydrocortisone, 4 have received methylprednisolone at 9 - 10 days after the onset of fever. In the same way, out of those in the placebo, 6 have received methylprednisolone. The patients who had faced severe symptoms had been treated with $500 \mathrm{mg}$ of MP daily for three days. Also, no improvement of lugs following MP was observed. The data of viral loads and their levels with days after fever for both groups of the study were displaced in two graphs. The peak plasma viral load was usually reached within the first week of illness and rapidly declined in the second week. However, SARS-CoV was to become undetectable in plasma was 12 days for hydrocortisone and placebo for 8 days respectively. Latter value of duration for viral clearance was concluded that there was no statistically significant value. It seems to be said that CSs did not significantly affect viral clearance though there was an incensed viral load following CSs treatment. Then they concluded viral lord was significantly incased following administration of CSs [12].

When the study was observed closely in the first three days of viral loads that were markedly reduced between 3 day to 5 days in the HC group. On the other hand viremia of the placebo group rapidly was going to reach its peak level on 5 to 6 the days. Also when the administration of MP was concerned there was no increased 
viral load and markedly reduction of viral load Thus the finding from these graphs reflects that there was a reduction of viremia in the early phase and late early phase of viral infection following administration of CSs. That means CSs involved markedly reduce replication of SARS coV. Then it can be concluded that reduction of viral load and viral replication has been brought by HC and an MP in an early phase of the illness. However, after three to four days of HC treatment, the viral lord was brought slightly to the initial level but did not go up at its peak level. Later the same level persists for a few days before went down it may strongly be due to over suppression of the immune cells done by HC. Moreover, HC causes the retention of water lading to a fluid overlord in the lung that may also contribute to increasing viral lord as well as worsening of the illness in some patients. Higher doses of MP for three days in late-stage may not also give a therapeutic effect to heal the lung injury unless it was limited to one day. It was because more suppression of immune cells for three days would not help to achieve rapid healing of immune damage tissue in the lung. These negative effects both MP and HC may contribute to achieving a lack of benefits from CSs administration in the illness. The same type of errors was identified and explained in dengue and steroid management studies [8-10].

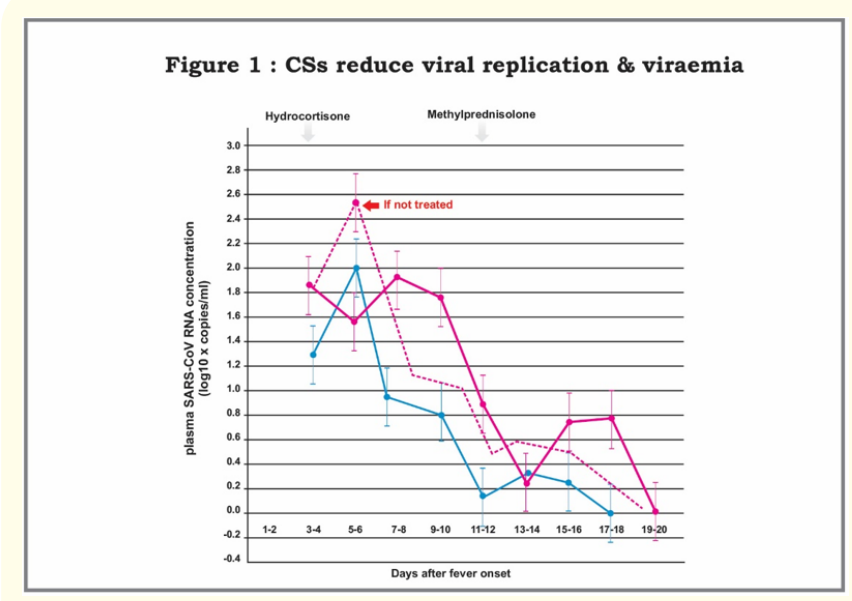

Figure 1: Hypothetical line (dotted line) shows the viral load in the HC group would have reached up to 2.9 at its peak level if not HC was administrated. Red line/upper line viral load following administration of HC and MP Blue/lowest line-viral load following placebo/nor use a drug line -(Figure drown by main author demonstrates hypothetical line if no administration of $\mathrm{HC}$ ) [copy the original figure -1 of the article informed to the author Professor LEE Lai Shun Nelson]

On the other hand, the initial detected viral load was higher in the hydrocortisone administrated group than the placebo group. The graph was shown that the virus lord of CSs group on the first day was 1.8 that is 0.6 higher than the placebo level on the first day.
It can be assumed that unless CSs were not administrated the natural peak level of the viral load in the HC group would have reached up to 2.9 at its peak level. According to statistical assessment levels after administration of the drug for two or three days the level of viremia (that should not go up) dramatically reduced to 1.3 level of HC group. Though there was a marked reduction of viremia compared with the imaginary peak level (if not the administration of HC) it was not pointed out in the study. Thus it can be hypothesized that If the drug was stopped after 3 days the viremia would have been dramatically reduced before the placebo group level because of no immune suppression.

Also, HC has poor tissue penetrating ability and lower receptor affinity compared with MP that has a very higher level of receptor affinity than HC [15]. This feature of MP might contribute to having no significant viremia or viral load in this study as well as other dengue study [8-10]. The immunological theory behind the reduction of the viral load must be due to the potent inhibitory effect of CSs on the production of PGE-2. PGE2 can play a role in viral infection directly by increasing the production and release of virions, inhibiting viral binding and replication, and/or stimulating viral gene expression [16,17].

Thus, the past experience administration of corticosteroids in early stage of viral illness and the research findings of observation of Lee $\mathrm{N}$ and his collogues, give very important conclusions that management guideline. A few of them are as follows apart from the above explanations. Over suppression of immune cells should not be done in the early phase of viral infection by adding more water retention CSs like HC. Therefore HC should not be used in the management of COVID -19 patients who are at higher risk of pulmonary edema. HC and MP may contribute to the rapid reduction of viremia and MP did not contribute to incase viral lord. Therefore therapeutic window (time duration) to reduce viral load and avoid the development of viral load in the early phase for HC may be within three days of a few doses of HC after fever onset. However, these conclusions and hypotheses should be further validated following ,well design double-blind control trial studies according to proper medical science if it is necessary for further evidence.

\section{A part of the statistical summary of Lee $\mathbf{N}$ and his colleagues' research}

The study claims that there was no methylprednisolone effect. This conclusion has been made from the outcome of the analysis of methylprednisolone group vs non-methylprednisolone after pooling data across hydrocortisone and placebo groups. The danger of this is that very often interaction can mask the main effects and thereby can easily make misleading conclusions. Moreover, since only one patient has been there for placebo and non-methylprednisolone, altogether non-methylprednisolone group has been dom- 
inated by the group that received hydrocortisone in early stages and subsequent non-methylprednisolone. By looking at the placebo curve from 9 - 10 days onward (Figure 2), what we see is the virus load to placebo and subsequent methylprednisolone. If we had a separate curve for placebo without subsequent methylprednisolone only, then only we can see the impact of methylprednisolone. However, that cannot be investigated in this study since there was only one patient for that combination. Thus, concluding no methylprednisolone effect from this study is invalid. To see the correct situation, further research with better planning is essential.

The study claims that there was no methylprednisolone effect. This conclusion has been made from the outcome of analysis of methylprednisolone group vs non-methylprednisolone after pooling data across hydrocortisone and placebo groups. The danger of this is that very often interaction can mask the main effects and thereby can easily make misleading conclusions. Moreover, since only one patient has been there for placebo and non-methylprednisolone, altogether non-methylprednisolone group has been dominated by the group that received hydrocortisone in early stages and subsequent on-methylprednisolone. By looking at the placebo curve from 9 - 10 days onward what we see in second graph is the virus load to placebo and subsequent methylprednisolone. If we had separate curve for placebo without subsequent methylprednisolone only, then only we can clearly see the impact of methylprednisolone. However, that cannot be investigated in this study since there was only one patient for that combination. Thus, making a conclusion of no methylprednisolone effect from this study is invalid. In order to see the correct situation, further research with better planning is essential.

There is no significant increase of virus load after receiving methylprednisolone according to second graph, most of the time the indication is a decrease in virus load after receiving methylprednisolone. This can also be verified by having better planned study with several patients on placebo and no methylprednisolone. In fact, we might even find introducing methylprednisolone at the early stages, instead of hydrocortisone to be effective.

\section{Standard management of COVID-19}

Personal protection and environmental hygiene were not explained here and this review is limited to introduce a treatment plan for COVID- 19. According to naval coronavirus pneumonia diagnosis and treatment plan for COVID 19 has been recommended by the Chinese authority as follows [18].

When the infection was mild following support have been given bed rest, support cars, maintains of caloric intake, attention to the balance of liquids and electrolytes, maintenance of homeostasis close monitory of patients vital signs and oxygen saturation. Apart from mild cases, all others should be closely monitored by assessing and investigating. it was done as follows, hematological panel monitoring, routine urine analysis, PCR, biochemistry (liver enzyme, cardiac enzymes kidney function) coagulation, arterial blood gas analysis, chest X-ray, CT scan if indicated, cytokine analysis if possible). In hypoxic conditions administration of effective oxygenation measures immediately including nasal catheter, oxygen mask and high-flow nasal cannula were used to manage the moderate to severe conditions Meanwhile antiviral therapies interferon alfa, umifenovir, Lopinavir or ritonavir, remdesivir ,antimalarial drug chloroquine, were administrated as an antiviral drug according to specific indications and on physicians advised and recommendations. Moreover, Cytokine blocking drugs (tocilizumab, sarilumab, baricitinib etc.), it included monitor side effects and considers the contraindications of the drugs. Also, antibiotic therapy was added when it was indicated to the particular patients However it was adhered to avoid unwanted or inappropriate use of antibiotics and specially used of broad-spectrum antibiotics [18].

All existing drugs are currently practiced except methylprednisolone to the main guideline that has a wide area of actions covering all immunological dysfunction.

\section{Existing drugs therapy in COVID-19}

Table 1 summarizes the drug treatment and their actions in COVID-19 concerned except Methylprednisolone (MP) MP has been recombined in the late stage of COVID-19 management when viremia is subsided. Compared with other agents, MP has broad-spectrum benefits activities in the disease pathology if the inhibitory effect on viral replication has been proven.

\section{Hydroxychloroquine}

Clinical trials of hydroxychloroquine (HCQ) treatment for Covid-19 pneumonia are underway in china (nct04261517 and nct04307693). The first study (nct04261517) has shown positive preliminary outcomes in terms of clinical management, with published data expected soon. HCQ in preventing secondary SARScov-2 infections and disease symptoms among all contacts has been proposed [19]. whether HCQ is as efficacious as chloroquine (CQ) in treating SARS-cov-2 infection still lacks the experimental evidence [19]. More details are on the table.

\section{Antiviral drugs}

They are administered shortly after symptom onset that can reduce infectiousness to others by reducing viral shedding in the respiratory secretions of patients SARS-cov-2 viral load in sputum peaks at around 5 - 6 days after symptom onset and lasts up to 14 days) and targeted prophylactic treatment of contacts could reduce their risk of becoming infected [20,21]. Patients with COVID-19 in China, 89.9\% were given antiviral drugs redeliver is a nucleoside analog prodrug developed by Gilead sciences [20,21]. 


\section{Cuban interferon alfa-2B}

Recombinant Interferon alfa-2B has been introduced to control the epidemic (COVID-19) caused by Coronavirus (SARS-CoV-2). That is used to stat and increase the antiviral activity and ameliorate the other immunological damages to cause fatal illness [22].
Cytokine blocking drugs (tocilizumab, sarilumab, etc.)

They can reduce the inflammatory storm that leads to death. Cytokines are inflammatory messenger molecules that can spin out of control with COVID-19 [18]. Though a few recommended non steroids immune suppressive drugs have been allowed in the

Table 1: Shows available standard drugs treatments that are currently used except methyl prednisolone.

\begin{tabular}{|c|c|c|c|c|c|}
\hline Subject & $\begin{array}{l}\text { Hydroxychloro- } \\
\text { quine }\end{array}$ & Interferon & Antiviral & TMPRSS2 inhibitor & Methyl prednisolone/CSs \\
\hline Action & $\begin{array}{c}\text { Interfering with } \\
\text { endosome/lysosome } \\
\text { trafficking or viral } \\
\text { protein matura- } \\
\text { tion during virions } \\
\text { maturation/limiting } \\
\text { the replication of } \\
\text { SARS-CoV-2 / in vi- } \\
\text { tro. IL-6), IL-12 p19, } \\
\text { IL-12 p40 and tumor } \\
\text { necrosis factor }\end{array}$ & $\begin{array}{c}\text { Produce viral RNA } \\
\text { enzymes, which } \\
\text { are responsible for } \\
\text { destroying the RNA } \\
\text { of some viruses. E.g. } \\
\text { SARS-CoV-2 }\end{array}$ & $\begin{array}{l}\text { Reducing viral } \\
\text { shedding }\end{array}$ & $\begin{array}{c}\text { Block entry of SARS- } \\
\text { CoV-2 for S protein } \\
\text { priming }\end{array}$ & $\begin{array}{c}\text { Inhibit viral replication by inhibitory action } \\
\text { on viral gene expression, reduce viral lord } \\
\text { leading to increase interferon actions, Inhib- } \\
\text { it apoptosis and protect cells and Reduces } \\
\text { cytokines, Reduce viral lord causes reduc- } \\
\text { ing cytokines cytokines-allow interferon } \\
\text { to function, Suppress immune cells and } \\
\text { neutrophil aggregation and recruitment, } \\
\text { Excessive recruitment of immune cells, } \\
\text { monocytes. Neutrophil and lymphocyte, } \\
\text { stop and prevent depletion of immune cells, } \\
\text { inhibit compliment path way and stop viral } \\
\text { pathology, protectant and prevent Down } \\
\text { regulation of AEC-2 by reducing viral lord, } \\
\text { prevent or restarted auto antibody forma- } \\
\text { tion and their severity of actions, suppress } \\
\text { excessive formation of chemokine and } \\
\text { cytokines, increase IL-10. }\end{array}$ \\
\hline $\begin{array}{l}\text { Side } \\
\text { effect }\end{array}$ & $\begin{array}{c}\text { Cardio toxicity is } \\
\text { a rare but serious } \\
\text { complication of HCQ }\end{array}$ & $\begin{array}{c}\text { Recommend caution } \\
\text { may cause adverse } \\
\text { reactions in some } \\
\text { patients. }\end{array}$ & $\begin{array}{l}\text { Cardiac insuffi- } \\
\text { ciency, arrhyth- } \\
\text { mia or other } \\
\text { cardiovascular } \\
\text { disorders. }\end{array}$ & $\begin{array}{l}\text { Anticoagulants with } \\
\text { significant and po- } \\
\text { tentially dangerous } \\
\text { clinical effects and } \\
\text { side effects }\end{array}$ & $\begin{array}{c}\text { High dose and prolong CSs administration } \\
\text { gives side effect, high fatality, prolong hos- } \\
\text { pital stay, viral lord sue to over suppression, } \\
\text { side effects, fungal infection, hyperglycemia, } \\
\text { secondary infection }\end{array}$ \\
\hline Used in & $\begin{array}{c}\text { In treated guidelines } \\
\text { of both South Korea } \\
\text { and China against } \\
\text { COVID-19 }\end{array}$ & $\begin{array}{l}\text { Patients with CO- } \\
\text { VID-19 in China/ } \\
\text { CUBA /USA }\end{array}$ & $\begin{array}{c}\text { COVID-19 in } \\
\text { China, } 89.9 \% \\
\text { were given/USA }\end{array}$ & $\begin{array}{l}\text { Patients with CO- } \\
\text { VID-19 in China }\end{array}$ & Immune suppression in many diseases \\
\hline
\end{tabular}

management have slow action compared with rapidly acting highly tissue penetrating and receptor binding MP. However CSs are not recommended in early or middle stage of illness in the standard protocols. However MP has broad spectrum immune modulatory activity, antiviral and immune suppressive activities ( table 01) that have been well explained its clinical application in dengue reviews [8-10].

\section{Inhibitor of the cellular serine protease TMPRSS2}

Cell entry of coronaviruses depends on the binding of the viral spike (S) proteins to cellular receptors and $S$ protein priming by host cell proteases. It was demonstrated that ARS-CoV-2 uses the SARS-CoV receptor ACE2 for entry and the serine protease TMPRSS2 for S protein priming. Naval drug proposed for COVID19 by Japan scientists a TMPRSS2 inhibitor approved for clinical use blocked entry and might constitute a treatment option which is employed by SARS-CoV-2 for S protein priming [23].

\section{Alternative therapy proposed for COVID-19}

Apart from standers practice to management of COVID-19, some western medicinal, non-medicinal and indigence medicinal drugs are popularly practiced among the different communities in a country. Some of them are explained in our views and according to medical sciences that are being practiced as follows.

\section{Sodium chloride}

Salt-coated filters proved highly effective in deactivating influenza viruses regardless of subtypes and the following storage in harsh environmental conditions. It was demonstrated that the developed salt-recrystallization based filtration system provides high filtration efficiency and successfully deactivates multiple subtypes 
of adsorbed viruses [24]. Thus, it can be suggested that gurgling of Salt may have a benefit of antiviral activity but laryngitis may arise as side effect of strong salt that is not good for any infection.

\section{Melatonin}

It was observed that very low fatalities recorded for infected COVID-19 patients under the age of nine [25,26]. It was proposed that his effects were brought by melatonin, an endogenous indoleamine and was the highest concentration in childhood as well as more in third-trimester pregnant mothers than others and lowest in old ages [26]. This might be the reason the fatality rate of COVID 19 increases linearly with age [25]. Melatonin has anti-inflammatory effects by inhibiting nuclear factor-kappa B (NF- $\mathrm{kB}$ )-mediated inflammatory responses and gives protective effects against the activation of the inflammasomes and, in particular, the NLRP3 inflammasome [27]. Adequate sleep and recommendation of mela- tonin can be proposed to harvest some benefits effects against viral immune pathology.

\section{Ascorbic acid}

This vitamin involves multiple vital physiological and metabolic processes. As an antioxidant molecule, vitamin $\mathrm{C}$ scavenges free radicals to protect cellular molecules from oxidative damage. Moreover, vitamin $\mathrm{C}$ has an anti-inflammatory effect and thus has a therapeutic role in sepsis, a systemic inflammatory syndrome mediated by inflammasome-dependent pyroptosis and pro-inflammatory cytokines such as IL-1 $\beta$ [28]. This may give additional benefits to protect against viral infection.

Indigence medicine and alternatives used in COVID-19

The rate of infectivity of SARS coV-2 and death due to COVID-19 in Sir Lanka are varied lower compared with other countries. It is

Table 2: It explains the biological active ingredients and their actions of herbal products. Chemical stretches are displaced in the table. (See refinance under the descriptions of the herbal products in each topic). 2.2 Chemical structures of anti-inflammatory and anti-viral substances. (western drugs and indigenous substances.)

\begin{tabular}{|c|c|c|c|c|c|}
\hline Subject & Camellia sinensis (Tea) & $\begin{array}{c}\text { Coscinium fenestratum } \\
\text { (venivalgata) }\end{array}$ & $\begin{array}{l}\text { Virgin coconut } \\
\text { oil (VCO), }\end{array}$ & Carica papaya & $\begin{array}{l}\text { Allium sativum } \\
\text { (garlic) }\end{array}$ \\
\hline $\begin{array}{l}\text { Active } \\
\text { Chemical } \\
\text { compound }\end{array}$ & $\begin{array}{c}\text { Green tea polyphenols h/ } \\
\text { Flavonoids/ catechins un- } \\
\text { der the group of flavones } \\
\text { epigallocatechin gallate } \\
\text { (EGCG) }\end{array}$ & $\begin{array}{l}\text { Berberine, } \\
\text { protoberberine } \\
\text { and jatrorrhizine }\end{array}$ & $\begin{array}{l}\text { lauric acid(C12) } \\
\text { and monolaurin } \\
\text { capric acid (C10) } \\
\text { and monocaprin }\end{array}$ & cetin & $\begin{array}{l}\text { Diallyl thiosulfinate } \\
\text { allyl methyl thiosul- } \\
\text { finate, methyl allyl } \\
\text { thiosulfinate, ajoene, } \\
\text { alliin }\end{array}$ \\
\hline Effects & $\begin{array}{c}\text { anti-oxidative } \\
\text { anti-inflammatory, } \\
\text { antibacterial } \\
\text { and antiviral activities / } \\
\text { effective against hyper- } \\
\text { cholesterolemia and } \\
\text { hyperglycemia/ }\end{array}$ & $\begin{array}{l}\text { Antioxidant effect anti } \\
\text { bacterial gram-positive } \\
\text { as well as gram-negative } \\
\text { bacteria selective inhib- } \\
\text { itory-Clostridium tetani/ } \\
\text { antiviral anti-herpes } \\
\text { simplex }\end{array}$ & $\begin{array}{l}\text { Disintegration of } \\
\text { the virus mem- } \\
\text { brane/Inhibits } \\
\text { virus maturation. } \\
\text { Prevents binding } \\
\text { of viral proteins } \\
\text { to the host cell } \\
\text { membrane. }\end{array}$ & \begin{tabular}{|c|} 
High binding against \\
NS2B-NS3 protease, \\
inhibit virus replica- \\
tion/potential im- \\
mune suppression/ \\
anti- inflammatory \\
actions
\end{tabular} & $\begin{array}{c}\text { Selected viruses } \\
\text { including, herpes } \\
\text { simplex virus type } 1 \text {, } \\
\text { herpes simplex virus } \\
\text { type } 2\end{array}$ \\
\hline $\begin{array}{l}\text { Chemical suture } \\
\text { MP }\end{array}$ & Epigallocatechin gallate & Berberine & Louric acid & Flavonoid quercetin & $\begin{array}{c}\text { Diallyl thiosulfinate., } \\
\text { et al. }\end{array}$ \\
\hline Application & $\begin{array}{l}\text { Proposed clinical study- } \\
\text { COVID19 }\end{array}$ & $\begin{array}{l}\text { Indigenes medical } \\
\text { practice }\end{array}$ & $\begin{array}{c}\text { Proposed clinical } \\
\text { study-COVID19 }\end{array}$ & $\begin{array}{l}\text { Proposed, covid19 } \\
\text { dengue, Zika virus }\end{array}$ & Antiviral properties \\
\hline
\end{tabular}

suspected that it might be due to the high intake of house-made indigence medicine. Past unofficial reports in local newspapers revealed that a very high amount of indigence medicinal dry materials have been bought of by Sri Lankans (Table 2). It explains the biologically active ingredients of herbal products and their actions.

\section{Green tea (Camellia sinensis)}

Unofficial China news also revealed the low rate of Infectivity in some community may be due to the intake of several cups of tea per day. Green tea has polyphenols harbors that have a wide spectrum of activities against different ribonucleic acid (RNA) and deoxyribonucleic acid (DNA) viruses. The antiviral activity of EGCG molecules of polyphenol depends on the interaction involving S1 proteins of BCV. It anti-viral activity of EGCG cover was found to cover Herpice, hepatitis B adenovirus, and coronavirus viral Influenza virus hepatitis B virus [29]. 


\section{Coscinium fenestratum (Gaertn.) Colebr}

The medicinally active compound is berberine, an isoquinoline alkaloid with numerous bioactivities [30] berberine has health beneficial effects such as antioxidant effect, anti-bacterial effects (gram-positive as well as gram-negative bacteria, selective inhibitory effects on -Clostridium tetani), antifungal activity and antiviral effects e.g. anti-herpes simplex activity [30].

\section{Virgin coconut oil (VCO)}

Prevents binding of viral proteins to the host cell membrane, inhibits virus maturation-lauric acid inhibited a late maturation stage in the replicative cycle of the Junin virus (JUNV). Sodium lauryl sulfate can solubilize and denature the viral envelope. It has been that monolaurin was able to reduce the infectivity of $14 \mathrm{hu}$ man RNA and DNA enveloped viruses in cell culture by $>99.9 \%$ and that monolaurin acted by disintegrating the virus envelope [31]. VCO and Omega-3a adjunctive Therapy for Hospitalized Patients with COVID 19, will be conducted at the Philippine General Hospital. In addition, NMKC Foundation in Sri Lanka has started primary work to conduct research using $\mathrm{VCO}$ as a preventive therapy for peoples in risk for SARS CoV-2 intentioned community or family as well as treatment to reduce viral load for hospitalized Patients with COVID 19. The foundation already planned to utilize the most purified VCO confirmed by internationally well recognized chemical laboratories.

\section{Carica papaya leaf extract}

Padmanaban Senthilvel and co-works showed that anti-dengue activity of extracts from Carica papaya can be due to flavonoid quercetin, which has high binding energy against NS2B-NS3 protease, that is crucial for dengue virus and Zika virus replication [32]. The latter cause severe respiratory diseases like SARS coV and take advantage of NS2B-NS3 protease to replicate [32]. Therefore, this flavonoid quercetin in the juice or table might be effective for COVID19 but it is not investigated or tested for nonstructural protein 3 (NS3pro) of SARS coV-2 and its association with NS2B-NS3 protease [32].

\section{Garlic (Allium sativum)}

It has been shown to have antiviral activity, but the compounds responsible have not been identified. Using direct pre-infection incubation assays. Diallyl thiosulfinate allyl methyl thiosulfinate, methyl allyl thiosulfinate, ajoene and alliin are some active chemical components of Garlic. The active compounds of the Garlic seem to be acted on selected viruses including, herpes simplex virus type 1 , herpes simplex virus type 2 and a few other viruses [33].

Lime- Citrus aurantifolia: It is an important medicinal and food plant widely cultivated in many parts of the world. The flavonoids have strong inherent ability to modify the body's reaction to al- lergens, viruses and carcinogens. One of them quercetin show antiallergic, anti-inflammatory, antimicrobial and anti-cancer activity one of the most active flavonoids possess significant anti-inflammatory activity because of direct inhibition of several initial processes of inflammation side effect. Antifertility activity C. aurantifolia juice caused irregularities of the estrous cycle, partially blocked ovulation [34].

\section{Practical use of alternative substances and practices}

Dr. Li Wenliang approach (LWA)- was named as an honor to late Dr. Li Wenliang who was an ophthalmologist in the Chinese city of Wuhan, died due to COVID 19. His observation of prevention of viral infection was not published in an acceptable international journals but popular in social media all over the world. His approach was to use stem inhalation, drink tea and hot water, milk four times per day. In fact the epigalocanate as an active ingredient, in green tea and other tea products can contribute to increase antiviral and anti-inflammatory effects against the viral infection.

Usage of anti-viral , anti-oxidant and anti-inflammatory medication in the incubation period and early stage of COVID-19 could not be seen. Therefor this could be considered as Inadequate Medical Approach (IMA) in a life threatening pandemic viral infection . Hela medical practices ageist viral disease includes smoke inhalation ,stem inhalation and drinking and used other herbal substances that has more than 4000 years history. Ayurveda medical practice consists similar approach but three are a few different approaches to both practices as well. Hela Medicinal Approach(HMA) is a partial stem bath for upper body (above the chest) for 5 to 10 minutes for three times per day. This HMA renders to lay out the evaporative active ingredient of herbal product in upper and lower respiratory epithelial surfaces and outer skin (Figure 02 - comparison between IMA and HMA).

In addition hot water and hot stream inhalation during the incubation periods and early stage of illness may contribute both directly and indirectly to completely or partially inactivate viruses in the air way and embodied in superficial mucus layer in the epithelium of the airway including para nasal sinuses'. In fact hot steam and hot water intake leads to fire the sympathetic out flow reducing edema and inflammation in and around nasal and ostial pathway to paranasal sinuses. It then causes to synthesis and release of healthy level of Nitric Oxide (NO) into both upper and lower airway tract. NO has potent antiviral and antibacterial activity that can inactivate the many viruses in the tract. On the other hand it was also proven that hot steam directly kill or inactivate many organisms on different surfaces [35]. Thus it can be hypothesized and said that the temperature in the stem and hot drinks could be able to kill or partially inactivated heat labile SARS Cov- 2 and many other respiratory viruses. However the viruses logging deep to the mucus 


\begin{tabular}{|c|c|c|}
\hline Subjects & $\begin{array}{l}\text { Hela medical approach } \\
{[\text { [HMA] }}\end{array}$ & $\begin{array}{l}\text { Li Wenliang's } \\
\text { approach } \\
\text { [LWA] }\end{array}$ \\
\hline Drinks & $\begin{array}{l}\text { Boil herbal products/ tea? four times per day } \\
\text { Aim - inactivate viruses, anti-inflammatory action. }\end{array}$ & $\begin{array}{l}\text { Boil water / tea ? } \\
\text { oral contact aria- } \\
\text { Inactivate viruses. }\end{array}$ \\
\hline $\begin{array}{l}\text { Steam } \\
\text { three-four } \\
\text { times per day }\end{array}$ & $\begin{array}{l}\text { Steam bath, vaporized herbal } \\
\text { ingredients / Aim - Inactivate viruses in upper and } \\
\text { lower respiratory track, Increase absorbtion of } \\
\text { herbal ingredient. }\end{array}$ & $\begin{array}{l}\text { Steam inhalation / } \\
\text { Aim - Inactivate } \\
\text { viruses in upper and } \\
\text { lower respiratory } \\
\text { track. }\end{array}$ \\
\hline $\begin{array}{l}\text { Method used } \\
\text { in stemming }\end{array}$ & $\begin{array}{l}\text { This steam inhalation is a partial stem Bath for upper } \\
\text { body (above the chest) for } 5 \text { to } 10 \text { minutes for three } \\
\text { times per day } \\
\text { Closed inhalation Similar to half steam Bath } \\
\text {-upper body } \\
\text { Two attempts at one occasion } 6-10 \text { mints / increase } \\
\text { body temperature } 38^{\circ} \mathrm{C}-40^{\circ} \mathrm{C} / \text { ingredient } \\
\text { substances are absorbed both skin and respiratory } \\
\text { epithelium. Aim- Inactivate viruses in the body }\end{array}$ & $\begin{array}{l}\text { Open ? Inhalation } \\
\text { of hot moisture } 3 \\
\text { to } 4 \text { times per day. }\end{array}$ \\
\hline $\begin{array}{l}\text { Other beneficial } \\
\text { Effects }\end{array}$ & $\begin{array}{l}\text { Reduced paranasal edema / increased } \\
\text { parasympathetic } \\
\text { activity/increased NO induced defense } \\
\text { Both drinking substances and absorption of active } \\
\text { ingredients in vapor promote antiviral, antibacterial } \\
\text { and anti-inflammatory activity. }\end{array}$ & $\begin{array}{l}\text { Reduce paranasal } \\
\text { edema / } \\
\text { increased } \\
\text { parasympathetic } \\
\text { activity/ increased } \\
\text { NO induced } \\
\text { defense/ Tea } \\
\text {-antiviral and } \\
\text { anti-inflammatory } \\
\text { effects }\end{array}$ \\
\hline $\begin{array}{l}\text { Additional } \\
\text { methods }\end{array}$ & $\begin{array}{l}\text { Drinking fresh milk (boiled less than } 90^{\circ} \mathrm{C} \text { ) increase } \\
\text { lactoferine action. Taking two spoon of coconut oil } \\
\text { (Gurgle using mainly virgin coconut oil) use other } \\
\text { antiviral plant oil/ use platht leaves steam/ } \\
\text { - antiviral anti- inflammmatory activity/assist clean } \\
\text { throat and reduced inflammation. Congee / fresh } \\
\text { milk /dry vaporize substance in smoke of herbal } \\
\text { products - Antiviral and anti inflammatory action } \\
\text { (not use for hypersensitivity patients and not use } \\
\text { overdose) }\end{array}$ & \begin{tabular}{|l|} 
Drinking fresh \\
milk - increase \\
lactoferine \\
Action - Anti \\
Inflammatory \\
antiviral actions
\end{tabular} \\
\hline Application & $\begin{array}{l}\text { During incubation and early phase of viral } \\
\text { infection, Herbal drink/ steam - used in early, middle } \\
\text { \& late phase and after the illness. }\end{array}$ & $\begin{array}{l}\text { During incubation } \\
\text { and early phase } \\
\text { of viral illnesses. }\end{array}$ \\
\hline
\end{tabular}

Table: Comparison approach between LWA and HMA.

layer or beyond the respiratory epithelium cells are not killed or inactivated by this approach.

The functional mask provided approximately $600 \mathrm{mg}$ of steam for 10 minutes and maintained an interior temperature of 38 $40^{\circ} \mathrm{C}$ for 15 minutes [36]. The dried virus of SARS CoV on smooth surfaces retained its viability for over 5 days at temperatures of $22-25^{\circ} \mathrm{C}$ and relative humidity of $40-50 \%$, that is, typical air-conditioned environments. However, virus viability was rapidly lost (> $3 \log 10$ ) at higher temperatures and higher relative humidity (e.g. $38^{\circ} \mathrm{C}$, and relative humidity of $>95 \%$ ) [37]. Thus, it can be suggested that viability of Viruses in body fluid (humidity of $100 \%$ ) must be lost when body temperature is artificially increased by intake of hot water and partial stem bath. As the virus has a high viability in typical air-conditioned environments that lowers the body temperature of patients the treated environment may not good for patients in the management of viral illness. Therefore, new study must be conducted to prove or disprove these arguments. Thus, hot steam is limited to preventive measures of a viral infection and not apply beyond the early stage of early illness or involvement of lung pathology. However antiviral activity following used to intake other measures can be used beyond the limit. Thus, LWT and HMT are proposed to be practiced in COVID-19 under the limited range without disturbance to the standard guide line.

Corticosteroids protocol to control and prevention of COVID-2019 immunopathology

\begin{tabular}{|l|c|c|}
\hline Undesirable effect & $\begin{array}{c}\text { Undesirable effects } \\
\text { due to }\end{array}$ & $\begin{array}{c}\text { Adjustment MP } \\
\text { to be used }\end{array}$ \\
\hline Side effect & Use not correct time & $\begin{array}{c}\text { Highly receptor } \\
\text { bound and } \\
\text { painting drugs }\end{array}$ \\
\hline Secondary infection & High or prolog usage & $\begin{array}{c}\text { Short periods } \\
\text { less than 3 days }\end{array}$ \\
\hline $\begin{array}{l}\text { High motility and } \\
\text { morbidity rate }\end{array}$ & $\begin{array}{c}\text { High doses, prolong } \\
\text { use age }\end{array}$ & $\begin{array}{c}\text { Low and short } \\
\text { duration }\end{array}$ \\
\hline $\begin{array}{l}\text { Prolong hospital } \\
\text { stay or intensive } \\
\text { care stay }\end{array}$ & $\begin{array}{c}\text { Excessive immune } \\
\text { suppression }\end{array}$ & $\begin{array}{c}\text { Short and exact } \\
\text { type of CSs }\end{array}$ \\
\hline $\begin{array}{l}\text { No acts in moderate, } \\
\text { sever stage }\end{array}$ & $\begin{array}{c}\text { Not use of non- } \\
\text { genomic effect }\end{array}$ & $\begin{array}{c}\text { Use Genomic } \\
\text { doses }\end{array}$ \\
\hline $\begin{array}{l}\text { Deterioration of the } \\
\text { illness, }\end{array}$ & $\begin{array}{c}\text { Water retention CSs } \\
\text { due to HC }\end{array}$ & $\begin{array}{c}\text { Avoid side effects } \\
\text { by MP. }\end{array}$ \\
\hline $\begin{array}{l}\text { Prolongation of vial } \\
\text { lord }\end{array}$ & $\begin{array}{c}\text { Prolongation and } \\
\text { high doses }\end{array}$ & $\begin{array}{c}\text { Slow and } \\
\text { therapeutic }\end{array}$ \\
\hline $\begin{array}{l}\text { Prolongation of vial } \\
\text { lord }\end{array}$ & $\begin{array}{c}\text { Excessive suppres- } \\
\text { sion of immune cells }\end{array}$ & $\begin{array}{c}\text { Just suppresses } \\
\text { allow body to } \\
\text { react }\end{array}$ \\
\hline
\end{tabular}

Table 3: Fist Colum indicts the side effects observed in many clinical research on SARS CoV and influenza viral treatment. In second Colum indicates the causes to have a undesirable effects from the CSs. Last Colum shows how we can adjust the CSs doses, type of CSs, duration of administration of drugs.

WHO and CDC have to recommend not be used CSs in patients with COVID-19 pneumonia because of side effects and undesirable effects unless there are other indications (e.g. exacerbation of chronic obstructive pulmonary disease) [11]. Undesirable effects of CSs were solely not an error of CSs research. The negative effects were due to the not appropriate use of CSs in the study $[9,10]$. Following table 3 summaries the causes for lack of efficacy of CSs in the researches and adjustment of CSs to get the positive outcomes from the treatment (Table 3).

However, there is no consensus regarding the minimal effective dosage, length of treatment and the route of administration for systemic corticosteroid treatment in early, inter mediate and sever phases of COVID 19 like in DF/DSS/DHF in dengue disease proposed in 2019 [8-10]. In practice proposed protocol in this review for COVID -19, varied treatment regimens for five phrases have been adopted, based largely on the clinical experience, inves- 
tigation findings and many clinical trials in SARS CoV and a few information on SARS CoV-2 and related immunopathology induced by other viral infections.

In this review, we considered the doses, the type of steroids, the route of administration and the duration of steroids used for suppression of immune markers, to reduce pulmonary edema induced by immune reactions, reduce viral replication, inhibit the formation of autoantibody and complement activation. This protocol is proposed as a supportive guideline of steroids, to control immune pathology in COVID 19 that is not aggravated by CSs therapy mentioned in table 3. Therefore, patients who are treated with CSs are kept under observation on current COVID 19 management guidelines adding antiviral and preventing secondary infection with life supportive measures for severe cases. Also, the doses can be adjusted according to investigation findings, as well as the clinical condition. The protocol mainly focused on the early phases of the disease rather than end-stage when there are more tissue damages and vulnerable to secondary infections. However, this review suggests a new steroid protocol that is open to be changed on properly accepted evidence-based medicine and alteration is proposed.

\section{Proposed corticosteroids management for COVID-19}

It is named here as '5S 5T to the battle of COVID-19' that consists of five $\mathrm{S}$ and five $\mathrm{T}$. It is a new treatment plan that can be suggested to be practiced clinically within the existing currently internationally fixed COVID-19 management. This new proposal of management is aimed to reduce the death rate, number of infectivities and contuse follow up of post-CIVID-19 patients. Also, this practice has been included in all other existing management rather than only CSs concerned:

- [S-1] Strengthen of body immunity: Use of medicinal and indigence accepted practice and drugs to boost body immunity and avoid practices or use of things that cause reduce boy immunity.

- [S-2] Stop virus at the throat: It needs to practice all measures to stop the viral infection go beyond the throat or larynges. Some argue no point of prevention at the point because virus con directly loge in lung. However usual habit of viruses increase their viral load firstly in upper airway. In this background. It can be used to reduce viral load in the throat and upper airway because low viral load cannot fight with body immunity.

- [S-3] Stop viral replication: Viral replication can be inhibited by directly antiviral drugs, recommended PGE-2 inhibitors and usage of other alternatives currently effective and practiced traditionally.
- [S-4] Stop virus enters into cells: Cell entry of coronaviruses depends on the binding of the viral spike (S) of SARS co $\mathrm{v}$ and proteins to cellular receptors and S protein priming by host cell serine protease TMPRSS2. TMPRSS2 inhibitor approved for clinical use blocked the entry of virus [23]. The entry reduction is calmed by herbal medicine as well.

Techniques: Four techniques can be practiced to stop the ongoing COVID-19:

- [T-1] Lock down technique: Non genomic effects brought by the high dose of Methylprednisolone that limited the relies on immune markers by stabilization of cell membrane of immune cells.

- [T-2] Hybrid techniques: Standard accepted practiced and supportive practices. e.g. melatonin, green tea, virgin coconut oil, Coscinium fenestratum that should not alter or withdraw the stranded practice.

- [T-3] Tempering technique: Tapering of the CSs doses that help to take our body defense while treatment has been completed.

- [T-4] Pulsatile technique: A contuse low or high doses of CSs administration have given severe side effects in some instances therefore pulsatile administration of CSs is practiced clinically [40]. The body has a potent natural ability to cure itself of much viral illness as well as COVID 19. Therefore, the management should be finely adjusted doses, time duration, and type of CSs and root of administration so that the body gets adequate support rather than damages done by the administration of CSs.

- [5-T] Tissue preserving technique: The lung tissue and blood vessels are damaged by inflammation. An accumulation of exudation in the alveolar space occurs following leaking excaudate immune cells from blood vessels into alveolar-capillary space occur in COVID 19. Moreover acute development of decreased pulmonary compliance and arterial hypoxemia occurs in ARDS. It was proven that effect of acute lung injury can be attenuated by $5 \mathrm{mg} \bullet \mathrm{kg}^{-1} /$ dexamethasone in animal study [38]. Two doses of betamethasone $12 \mathrm{mg} /$ MP-60 mg IM 24 hours (doses given to mothers at risk in preterm delivery) can be suggested to give one or two day before develop early lung sings of ARDS in COVID-19 [39]. This should be proven before administration of drug.

[S-4] Sustained follow up: Post COVID-19 patents should be followed for years to avoid complications after COVID -19 illness.

Lockdown technique 
This is the most important technique using the highest therapeutic doses MP that lockdown immune cells that continually release and act excessively damaging cells and tissue structures in the lungs of the COVID-19 patients. Its pharmacological action was as follows. At high concentrations, glucocorticoid molecules intercalate into the cell membrane and alter cellular functions resulting in reduced calcium and sodium cycling across the plasma membranes of immune cells. This is thought to contribute to rapid immunosuppression and a subsequent reduction of the inflammatory process when corticosteroids are used in high concentrations [40]. Furthermore, considering the pharmacological aspect, the lowdose steroids may act via the genomic pathway of corticosteroids, whereas a high-dose of steroids may act through both genomic and non-genomic pathways [40]. When only a single glucocorticoid application is used, the effect would last only for a short duration because receptor occupation rapidly reverts to the original value. This is the importance of multiple doses to have a sustained effect [40]. Methylprednisolone may have a higher receptor affinity and quicker penetration of the cell membrane as well as lung tissue. Also, intravenous methylprednisolone shows a rapid peak rather than other CSs [40].

Corticosteroids used in phases of COVID-19

Pre preliminary phase

[S-I] Strengthen body immunity

Medical and non-medicinal drugs and precise can be used. Known antioxidants, medicinal and indigence accepted practice and drugs boost body immunity and it should avoid practices or use of things that cause reduce body immunity. This is the most important plan of management to reduce the number of infected patients in addition to a standard is known personal and environmental protection against the SARS CoV-2.

\section{[S-2] Stop viral load at the throat}

Throat viral load and upper airway viral load must be diminished It helps to stop the viral infection go beyond the throat or larynges and reduce viral lord significantly. It can be used to reduce viral load in the throat and upper airway.

Local spray and application: Ciclesonide, an inhaled corticosteroid, suppressed human coronavirus replication in cultured cells and the effective concentration of ciclesonide to block SARSCoV-2 (the cause of COVID-19) replication (EC90) was 6.3 Mm and can be candidate drug for treatment [41]. Habit of drinking liquid herbal product, green tea, and application or gurgling of virgin coconut oil, taking tablets of melatonin and vitamin $\mathrm{C}$ and herbal steam inhalation have been used by community. Effectiveness of them must be investigated against viral infections for future benefits. Local spry or application of antiviral and anti-inflammatory and antioxidant agent around nasal or oral aria must be introduced to safe guard peoples from the risk aria or contacts.

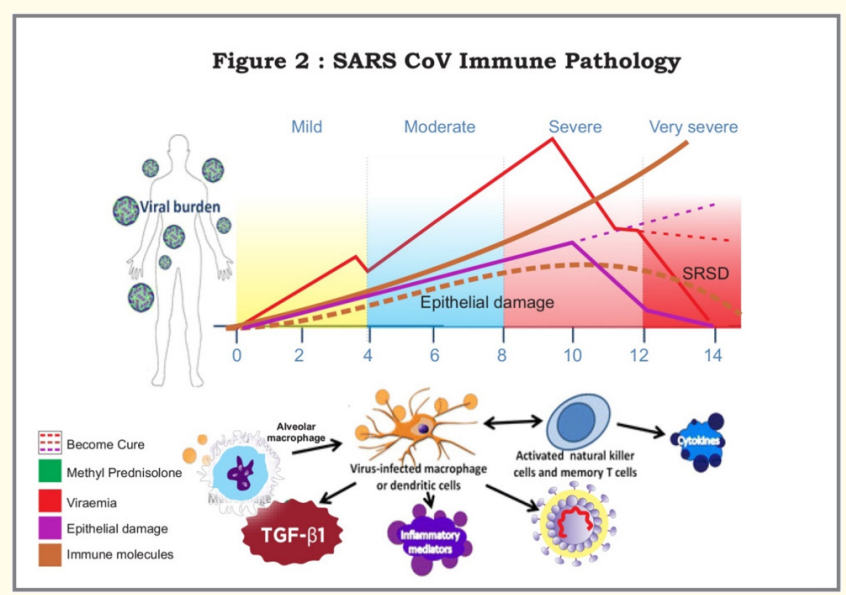

Figure 2: Shows viremia, immune molecules activation and epithelial damage during the cause of COVID 19. Hypothetical line (dotted line) indicates immune levels after administration of MP.

These practices can be used for people who are at risk in SARS2 infected area

1. People at risk are identified as infected SARS coV-2 contact persons and householders.

2. People who are at risk of infection; such as obese persons, pregnant mothers infants, and children, any contraindication for steroids must be considered in this.

3. Immune compromised patients (diabetics, cancer patients and others with suffering any other infections).

\section{Preliminary phase}

Steroid is indicated in early or early mild phase disease according to this management

[S-3] Stop viral replication: Viral replication can be inhibited by directly antiviral drugs, recommended PGE-2 inhibitors. If these are not valuable or contraindicated usage of other alternatives or substances used traditionally without side effects must be practiced.

- $\quad$ Early administration of steroids may stop the replication of the virus and may be reduced viremia no significant incensement of viral clearance [8-19]. Not more than two to three days of corticosteroids are administrated as a therapeutic window of MP in the early phase is limited.

- Mineralocorticoids and low receptor affinity and low tissue penetrating corticosteroids must be avoided (water retention 
and poor effectively CSs is harmful to the patients at risk of pulmonary pathology). Methyl prednisolone is the drug of choice if there are no contraindications.

- $\quad$ Though many patients recover well without severe squeal high viral lord and infectivity in SARS Co V indicted patients must be diminished so obviously steroid can give many benefits to all such patients and community to reduce spreads of the illness.

- $\quad$ All patients must be turreted with viral replicating inhibitors though a few patients do not recover well going to sever sequel. It is because this management reduces deaths, morbidity and ICU stay for a long duration. Thus, it reduces numbers of death and morbidity.

- $\quad$ The steroid should be used in patients with an independent indication for a steroid, such as:

- Vasopressor-refractory shock

- $\quad$ Asthma or COPD exacerbation [11].

Preliminary phase/very early phase (from the onset of fever) In this phase it is named from onset of fever to persistent/recurrent fever plus radiographic progression of lung opacities \pm hypoxemia.

\section{[S-3] Stop viral replication}

The recommended antiviral agent is proposed to administrat-

\begin{tabular}{|c|c|c|c|c|}
\hline Subject & Early & Middle & Sever & Post SARS co V \\
\hline $\begin{array}{l}\text { Effective CSs } \\
\text { Treatment } \\
\text { used in clinical } \\
\text { research }\end{array}$ & $\begin{array}{l}\text { hydrocortisone } 100 \mathrm{mg} \text { every } \\
\text { eight hourly/day } 3 \text { - } 4 \text { days after } \\
\text { fever onset that was continued } \\
\text { for } 7 \text { days/for pneumonic pts } \\
\text { methylprednisolone }(500 \mathrm{mg} / \\
\text { day for three consecutive days }\end{array}$ & $\begin{array}{c}\text { iv MP } 1.0 \text { - } 1.5 \mathrm{mg} / \mathrm{body} \\
\text { weight }(\mathrm{kg}) / \text { time, } 2-4 \\
\text { times/day, antiviral- osel- } \\
\text { tamivir was } 150 \mathrm{mg} / \text { day } \\
\text { for } 5 \text {, zanamivir was } 20 \\
\mathrm{mg} / \text { day for } 5 \text { days }\end{array}$ & $\begin{array}{c}\text { Loading dose MP of } 1 \mathrm{mg} / \\
\mathrm{kg} \text {, and then contrive for } \\
-14 \mathrm{~d} \text { was tail off, } 0.5 \mathrm{mg}- \\
\text { after } 7 \mathrm{~d} .0 .25 \text { after next }-7 \mathrm{~d}, \\
2.0 .5 \text { - } 2.5 \mathrm{mg} \text {.kg.d of MP for } \\
\text { long duration }\end{array}$ & $\begin{array}{l}\text { No history of treatment: } \\
\text { Lung fibrosis/other lung } \\
\text { complications /other im- } \\
\text { munological sequel /CVD/ } \\
\text { Hypertension/ } \\
\text { hyperlipidemia }\end{array}$ \\
\hline Advantage & $\begin{array}{c}\text { AUTHOR-incased viral lord/ } \\
\text { worse presentation of a few } \\
\text { OUR-reduced viremia, increase } \\
\text { viral lord due to over suppres- } \\
\text { sion by CSs, worse due to sodium } \\
\text { retention and accumulation of } \\
\text { fluid by HC }\end{array}$ & $\begin{array}{c}\text { No secondary infections, } \\
\text { reduce the time of critical } \\
\text { conditions and to prevent } \\
\text { disease progression to } \\
\text { severe pneumonia }\end{array}$ & $\begin{array}{l}\text { Improvement from mortality } \\
\text { morbidity outcomes without } \\
\text { increased adverse reactions }\end{array}$ & No History \\
\hline Reference & $\begin{array}{c}\text { Lee N Lee N, Allen Chan KC, } \\
\text { Hui DS, et al. J Clin Virol. } 2004 \\
\text { Dec;31(4):304-9.15 }\end{array}$ & \begin{tabular}{|} 
Hui Li, Shi-gui Yang, Li Gu, \\
Yao Zhang., et al. Influenza \\
Other Respir Viruses. \\
2017 Jul; 11(4): 345-354.
\end{tabular} & \begin{tabular}{|} 
Nasef Abdelsalam., et al. [1] \\
Tang BM, Craig JC, Eslick GD, \\
Seppelt I, McLean AS., et al. \\
Crit Care Med. 2009 [20]
\end{tabular} & \\
\hline
\end{tabular}

Table 4: The research data of effective protocol in the past CSs and viral disease.

ed early rather than pertinent go into sever stages of illness. The graph of high-grade clinical research showed that early days of administration of CSs in SARS co V infection reduce the viremia markedly within the first three days [12] (Table 4).

Use of oral corticosteroids at the preliminary phase (from the onset of fever)

A low oral dose of methylprednisolone $(8 \mathrm{mg})$ twice daily for one to three days

During the incubation period low oral dose of methylprednisolone ( $8 \mathrm{mg}$ ) twice daily for one to three days. This can be used for people who are living in COVID-19 epidemic areas or reinvested after recovery. (N.B). Anyhow this region is not recommended without medical advice it was not proven by studies). Therefore, non-steroids other agents can be used in these periods rather than without having any drugs.
A low dose of oral methylprednisolone ( $8 \mathrm{mg}$ ) three times a day (32 mg/day) for three days.

Patients with higher titers of anti-S Ig G antibodies or SARS coV-2 antigen without many symptoms in infected patients or post infected recurrences maybe benefit from 125 - 500 mg IV Methylprednisolone as a loading dose, while oral treatment is continued.

[T-1] Lock down technique: Patients who are (i) at risk of COVID 19 as above or clinically deteriorating (ii) CRP is high and other significant early ARDS signs, should be given $500 \mathrm{mg}$ - $1000 \mathrm{mg}$ IV Methylprednisolone or $30 \mathrm{mg} / \mathrm{kg}$ as a loading dose and $8 \mathrm{mg}$ of oral methylprednisolone three times a day (32 mg/day) and continued for three days and tapering.

Early middle phase: Though it was named as an early middle phase in covid19 when it is the critical period to save patients in healthily without going to ARDS. Moreover, rapidly increasing vi- 
remia and immune molecules and activation of immune cells are taken place in this short period (Figure 2).

[T-1] Lock down technique: Therefore, Membrane stabilization, inhibition of complement and modulation of immune components properties of CSs are suggested to get the benefits of the administration of higher IV doses of steroids during this critical period.

The use of corticosteroids at very early phases: IV 125 - $500 \mathrm{mg}$ of MP as a loading dose and 40mg MP per day of oral methylprednisolone continued for three days or can be repeated for 3 to 5 days according to severity.

[T-2] Tapering technique: Tapering of the corticosteroids helps to take our body defense to pick up while treatment has been completed lowing undesirable side effects of the drugs.

The use of corticosteroids in the early late phase: $500 \mathrm{mg}$ to $1 \mathrm{~g}$ IV of methylprednisolone for three days followed by $32-64 \mathrm{mg} / \mathrm{kg}$ of oral methylprednisolone with tapering for 7 days can be used.

[T-3] Hybrid techniques: The standard accepted protocol is practiced and supportive practices. e.g. melatonin, green tea, virgin coconut oil, Coscinium fenestratum that can be used in this method. However, this application should not alter or withdraw the stranded practice or obstacles. This must be added to control excess immune activity and reduce the corticosteroids side effects.

[5-T] Tissue preserving technique: This technique is proposed to prevent patients from going into ARDS [this should be proven before start the treatment].

Use of corticosteroids in the middle

In this review, the intermediate stage is considered the range from persistent/recurrent fever plus radiographic progression of lung opacities \pm hypoxemia to ARDS/SRDS. Pneumonia was defined as an acute lower respiratory illness with an opacity or infiltrate seen on chest radiography, which was interpreted as pneumonia by the treating physician.

This phase is also important to save patients without further lung damage if it is attempted early to rescue from the immune dysfunction crisis. No value of CSs for long-duration was found according to past clinical researches.

According to past research experience in SARS Co V and influenza pneumonia treatment following protocol were introduced in Pneumonia stages:

- Low doses: IV MP 1.0 - 1.5 mg/body weight (kg)/time, 2 - 4 times/day, in subjects under 15 years of age. They confirmed that this regime gave no secondary infections, reduce the

\begin{tabular}{|c|c|c|}
\hline Pre Early Phase & Early and middle phase & $\begin{array}{c}\text { Sever/Critical } \\
\text { Phase }\end{array}$ \\
\hline $\begin{array}{l}\text { Immediate after in- } \\
\text { fect pharmacological } \\
\text { effective percentage } \\
\text { of local a pray of cor- } \\
\text { ticosteroids in oral } \\
\text { and upper and lower } \\
\text { respiratory tract } \\
\text { (not followed as not } \\
\text { proven by a test). } \\
\text { During incubation } \\
\text { period -Low oral } \\
\text { dose of } 8 \text { - } 12 \text { mg } \\
\text { methyl prednisolone } \\
\text { twice daily for three } \\
\text { days }\end{array}$ & $\begin{array}{c}\text { Early IV } 125 \text { - } 500 \mathrm{mg} \\
\text { of MP as a loading dose } \\
\text { and } 40 \text { mg MP per day of } \\
\text { oral methyl prednisolone } \\
\text { continued for three days } \\
\text { or can be repeated for } 3 \text { - } 5 \\
\text { days. Middle } 500 \text { mg to } 1 \mathrm{~g} \\
\text { IV of methyl prednisolone } \\
\text { for three days followed } \\
\text { by } 12 \text { - } 20 \text { mg/kg of oral } \\
\text { methyl prednisolone with } \\
\text { tapering days. (Lording } \\
\text { dose- for children -IV } \\
\text { methyl prednisolone (MP): } \\
15 \mathrm{mg} / \mathrm{kg} \text { single dose) }\end{array}$ & $\begin{array}{c}\text { Early- } 500 \\
\text { mg to } 1 \mathrm{~g} \text { IV of } \\
\text { methyl pred- } \\
\text { nisolone for one } \\
\text { day followed by } \\
0.5 \text { - } 2.5 \mathrm{mg} . \mathrm{kg} . \mathrm{d} \\
\text { of MP for long } \\
\text { duration or MP } \\
\text { of } 1 \mathrm{mg} / \mathrm{kg} \text {, for } \\
-14 \mathrm{~d} \text { was tail } \\
\text { off, } 0.5 \mathrm{mg} \text { - af- } \\
\text { ter } 7 \mathrm{~d} .0 .25 \text { after } \\
\text { next }-7 \mathrm{~d} \text {. }\end{array}$ \\
\hline
\end{tabular}

Table 5: Summarizes the proposed doses of CSs in the management of Covid-19.

time of critical conditions and to prevent disease progression to severe pneumonia [42].

- Moderate doses: Of 25 - $150 \mathrm{mg} \mathrm{d}^{-1} \mathrm{MP}$, high-dose > $150 \mathrm{mg}$ $\mathrm{d}^{-1} \mathrm{MP}$ were given for $7 \mathrm{~d}$. It was confirmed that low-to-moderate-dose significantly reduced mortality [43] (Table 5).

[T-1] Lock down technique: Therefore "Lockdown technique" is suggested to been sued in this phase as well, High dose of MP $1 \mathrm{~g}$ for one or two doses are suggested in this middle phase and follow other protocol latter. It was practiced in severe dengue as well [8-10].

\section{Sever phase: Low dose steroid for patients with ARDS}

The last or end phase of severe respiratory viral infections (SRVIs) is named the period here to from Acute respiratory distress syndrome (ARDS) to death or recover from ARDS. Acute respiratory distress syndrome (ARDS) is an acute-onset hypoxic condition with radiographic bilateral lung infiltration. It is characterized by an acute exudative phase combining diffuse alveolar damage and lung edema followed by a later fibro proliferative phase.

Aim of this CSs therapy prevents lung fibrosis. High and moderate doses have caused a side effect; increase motility and prolongation of ICU stay an important protocol. The Human Airway Trypsin-like protease (HAT) and PGE-2 also reduce fibrosis in ARDS Continuous persistence high doses of CSs that reduce PGE-2 levels leading to more favor to develop fibrosis rather than recovery. Therefore, tapering Techniques in late stage is recommended [44].

\section{[T-2] Tapering technique}

Low doses: 0.5 - 2.5 mg.kg.d of MP for long duration [45]. It has a loading dose MP of $1 \mathrm{mg} / \mathrm{kg}$, and then contrive for - $14 \mathrm{~d}$ was tail off, $0.5 \mathrm{mg}$ - after $7 \mathrm{~d} .0 .25$ after next - $7 \mathrm{~d}$ [45]. This regime gives im- 
provement from mortality morbidity outcomes without increased adverse reactions. But the effectiveness of such a regime in the recovery phase must be evaluated by standard researches.

[T-1] Lock down technique: It is a value to add a high dose at the end-stage encumbers amount of immune marker is present in the body.

The use of corticosteroids at the middle-end phase: $500 \mathrm{mg}$ to $1 \mathrm{~g} \mathrm{IV}$ of methylprednisolone for one day followed by $1 \mathrm{mg} / \mathrm{kg} \mathrm{mg} /$ $\mathrm{kg}$ of oral methylprednisolone with tapering can be used.

Hydrocortisone or other steroids with high mineralocorticoid action and oral steroids should not be given during this phase because of worsening or risk of pulmonary edema.

Use of corticosteroids in the middle-end phase/ARDS: This phase is also important to save patients without further lung damage if the attempt is practiced at early to rescue period from immune dysfunction stat. In fact no value of CSs for long duration during the period according to past clinical research.

[T-1] Lock down technique: Therefor High dose of MP $1 \mathrm{~g}$ for one or two doses is suggested in this middle phase to reduce damages caused by excess immune cells and immune molecules and follow other protocols after using the lockdown technique. To evaluate the condition of the disease elevated inflammatory markers (e.g. C-reactive protein) can be used [11].

In one research iv MP 1.0 - $1.5 \mathrm{mg} /$ body weight $(\mathrm{kg}) /$ time, 2 - 4 times/day, in subjects under 15 years of age [45]. They confirmed that this regime gave no secondary infections, reduce the time of critical conditions and to prevent disease progression to severe pneumonia.

Regimens used in china: Methylprednisolone 40 - $80 \mathrm{mg}$ IV daily for 3 - 6 days, which seems reasonable [46]. Equivalent doses of dexamethasone (7 - $15 \mathrm{mg}$ daily) could have an advantage of stimulating less fluid retention since dexamethasone has less mineralocorticoid [11].

\section{Post-COVID-19 syndrome}

A set of medical signs and symptoms after post COVID 19 which are correlated with each other on immunological based that is known as post COVID 19 complication syndrome (PCCS) in this review.

[4-S] Sustained follow up: Approach is conducted here to avoid sever and rest of morbidity dolloping COVID-19.

[S-4] Sustained follow-up: The late recovery phase is named here the conditions Following COVIS-19. Also, this is the last argument of 4S4T for COVID -19. In these phases also the hybrid techniques for COVID-19 can be applied that includes standard drug management for the illness, added with immune-modulatory substances like melatonin, green tea or herbal medicine products. However, there are no studies done so far for post-COVID complication syndrome.

\section{Use of corticosteroids in the early recovery phase}

Early recovery phase: A daily dose of $32 \mathrm{mg}$ oral methylprednisolone for three days is recommended. If patients test positive for higher titers of anti-dengue IgG antibodies or other immune markers, oral methylprednisolone should be continued as mentioned in the late recovery phase.

[T-1] Lock down technique: Some patients develop a cytokine storm marked by progressively rising inflammatory markers, fever, and eventually distributive shock [11]. This level of inflammation may fail to respond to low doses of steroids (e.g. methylprednisolone 60 mg IV daily). Higher doses may be needed (e.g. 100 - 125 mg IV q6hr x1-3 days). No data is available on this currently [11].

Intermediate recovery phase: In this phase, the treatment should be followed by oral methylprednisolone $32 \mathrm{mg}$ per day for seven days and tailed off gradually within the 1 to 2 months.

Late recovery phase: Patients with hypertension or other illness with positive for higher titers of anti-S IgG antibodies or other immune markers are candidates for this treatment protocol. It is suggested to treat them with $32 \mathrm{mg}$ per day of oral methylprednisolone for seven days and tail off gradually within 2 months or use other immune-suppressive drugs recommended by a physician.

\section{Conclusion}

“5S 5T management to the battle of COVID -19" has been included all existing practices relevant to accepted medical sciences to control of ongoing COVID-19. Management of sever immune dysfunction using CSs has been limited due to high fatality and undesirable effects. Though the not to use corticosteroids according to the evidence was true the negative outcome was due to poor plan to CSs doses administrated, poor design of duration and type of CSs used. The researches were found to be not adjusted to get the desirable effects. This proposed protocol include five Ss (Strengthen of body immunity, Stop virus at throat, Stop viral replication, Stop virus enters into cells and Sustained follow up) and five Ts (Lock down technique, Hybrid techniques, Tissue preserving technique, Tapering Technique, Pulsatile technique). Further clinical trials using pharmacologically and immunologically accepted standard steroid protocols for corticosteroids and alternative approaches. The value of such a scientific explanation and steroid treatment 
protocol management of COVID-19 cannot be underestimated. Leaving aside or attempting to ignore, the value of steroid treatment, seems to be a marked deficient and inaccurate approach in the field of immunology, pathology.

\section{Ethical Approval}

Not required.

\section{Availability of Data and Material}

The data set for this publication is available upon request from the authors.

\section{Competing Interests \\ None to declare.}

\section{Funding}

None.

\section{Author Contributions}

SMRB; Formulated hypotheses on following topics such Corticosteroid actions on viral (SARS co V-2 SARS coV, dengue) immune pathology effectiveness of corticosteroid in COVID-19 treatment and management of COVID-19 and post viral Syndrome hypothesis forCOVID19, devised the project and review articles, the main conceptual ideas and proof outline wrote the manuscript, SS: analyzed statistical part of the research data and supervised the review. ASSSH and SMTNS: extracted and reviewed the literature of chemical ingredients of herbal products, SMTNS. extracted and reviewed the literature of SARS CoV-2 infections and immunology and chemical ingredients of non-herbal products. All authors read and approved the final manuscript.

\section{Acknowledgement}

I thank all the researchers and their medical and non-medical staff for their dedication to do research on dengue related topics and publishing them for past few decades.

I am most grateful to all authors contribute to end this task and for their support in writing this review.

I would also like to acknowledge the support of medical officers outpatients department at teaching hospital Peradaniya and the director and deputy directors and the administrative staff at the Teaching Hospital, Peradaniya, The director general and deputy

\section{Bibliography}

1. Wang C., et al. "A novel coronavirus outbreak of global health concern". Lancet 395 (2020): 470-473.

2. Xu X., et al. "Evolution of the novel coronavirus from the ongoing Wuhan outbreak and modeling of its spike protein for risk of human transmission". Science China Life Sciences (2020).
3. World-Health-Organization Statement on the second meeting of the International Health Regulations (2005).

4. Ewen Callaway., et al. "The coronavirus pandemic in five powerful charts". Nature (2020).

5. Mary Van Beusekom. “Deeply concerned' WHO declares COVID-19 pandemic" (2020).

6. COVID-19 Coronavirus Pandemic (2020): 23.

7. Chan JFW., et al. "Genomic characterization of the 2019 novel human-pathogenic coronavirus isolated from a patient with atypical pneumonia after visiting Wuhan". Emerging Microbes and Infections 9 (2020): 221-236.

8. S M Rathnasiri Bandara., et al. "Management of Dengue and Post Dengue Complication Syndrome: A Review". ACTA Scientific Microbiology 2.4 (2020).

9. SM Rathnasiri Bandaraa and HMMTB Herathb. "Effectiveness of corticosteroid in the treatment of dengue - A systemic review". Heliyon 4.9 (2018): e00816.

10. SM Rathnasiri Bandara and HMMTB Herat. Corticosteroid actions on dengue immune pathology; A review article (2019).

11. Interim Clinical Guidance for Management of Patients with Confirmed Coronavirus Disease (COVID-19). CDC. Coronavirus Disease 2019 (COVID-19) (2019).

12. Lee N., et al. "Wong Effects of early corticosteroid treatment on plasma SARS-associated Coronavirus RNA concentrations in adult patients". Journal of Clinical Virology 31.4 (2004): $304-$ 309.

13. Sasmita Poudel Adhikari., et al. "Epidemiology, causes, clinical manifestation and diagnosis, prevention and control of coronavirus disease (COVID-19) during the early outbreak period: a scoping review". Infectious Diseases of Poverty 9.1 (2020): 29.

14. Ying-Ying Zheng., et al. "COVID-19 and the cardiovascular system". Nature Reviews Cardiology (2020).

15. Sinha A and Bagga A. "Pulse steroid therapy". Indian Journal of Pediatrics 75.10 (2008): 1057-1066.

16. Steer SA and Corbett JA. "The role and regulation of COX-2 during viral infection". Viral Immunology 16.4 (2003): 447-460.

17. Lin C-K., et al. "Cyclooxygenase-2 facilitates dengue virus replication and serves as a potential target for developing antiviral agents". Scientific Reports 7.1 (2017): 299. 
18. Kenneth McIntosh., et al. "Coronavirus disease 2019 (COVID-19)" (2020).

19. Jia Liu., et al. "Hydroxychloroquine, a less toxic derivative of chloroquine, is effective in inhibiting SARS-CoV-2 infection In vitro". Cell Discovery (2020).

20. Welliver R Monto., et al. "Effectiveness of oseltamivir in preventing influenza in household contacts: a randomized controlled trial". Journal of the American Medical Association 285 (2001): 748-754.

21. Holshue ML., et al. "First case of 2019 novel coronavirus in the United States". The New England Journal of Medicine (2019).

22. Recombinant Interferon alfa-2B, a leading Cuban biotechnology product... the epidemic (COVID-19) caused by Coronavirus (SARS-CoV-2) (2020).

23. Markus Hoffmann., et al. "SARS-CoV-2 Cell Entry Depends on ACE2 and TMPRSS2 and Is Blocked by a Clinically Proven Protease Inhibitor" Journal Cell (2020).

24. Fu-Shi Quan., et al. "Universal and reusable virus deactivation system for respiratory protection". Scientific Reports (2017).

25. Coronavirus Age, Sex, Demographics (COVID-19)-Worldometer (2020).

26. Frequently Asked Questions and Answers: Coronavirus Disease-2019 (COVID-19) and Children (2019).

27. Moniruzzaman M., et al. "Melatonin ameliorates $\mathrm{H}_{2} \mathrm{O}_{2}$-induced oxidative stress through modulation of Erk/Akt/NFkB pathway". Biological Research 51 (2018): 17.

28. Xuesong Sang., et al. "Vitamin C inhibits the activation of the NLRP3 inflammasome by scavenging mitochondrial ROS". Inflammasome 2 (2016): 13-19.

29. Jose Martinez., et al. "Antiviral effects of green tea (Camellia sinensis) against pathogenic viruses in human and animals (a mini-review)". Article in African Journal of Traditional, Complementary and Alternative Medicines (2016).

30. KV Tushar., et al. "Coscinium fenestratum (Gaertn.) Colebr.-A Review". Journal of Plant Sciences 3 (2008): 133-145.

31. Fabian M Dayrit and Mary T Newport. "The Potential of Coconut Oil and its Derivatives as Effective and Safe Antiviral Agents Against the Novel Coronavirus (nCoV-2019)".
32. Dahai Luo and Julien Lescar "The flavivirus NS2B-NS3 protease-helicase as a target for antiviral drug development". Journal of Antiviral (2015).

33. Weber ND., et al. "In vitro virucidal effects of Allium sativum (garlic) extract and compounds". Planta Medicine 58.5 (1992): 417-423.

34. Onyilofe Sunday Enejoh., et al. "Ethnomedical Importance of Citrus aurantifolia (Christm) Swingle". The Pharma Innovation Journal 4.8 (2015): 1-6.

35. Benjamin D Tanner. "Contaminated surfaces with a novel, portable, saturated steam vapor disinfection system". American Journal of Infection Control 37.1 (2008): 20-27.

36. Tomohisa Ichiba., et al. "Warm Steam Inhalation before Bedtime Improved Sleep Quality in Adult Men". Evidence-Based Complementary and Alternative Medicine (2019): 2453483.

37. KH Chan., et al. "The Effects of Temperature and Relative Humidity on the Viability of the SARS Coronavirus". Advances in Virology (2011): 734690.

38. J Sun., et al. "Effects of curcumin or dexamethasone on lung ischaemia-reperfusion injury in rats". European Respiratory Journal 33 (2009): 398-404.

39. Julie Brown., et al. "Antenatal corticosteroids for accelerating fetal lung maturation for women at risk of preterm birth". Cochrane Database of Systematic Reviews 3 (2017): CD004454.

40. Sinha A and Bagga A. "Pulse steroid therapy". Indian Journal of Pediatrics 75.10 (2008): 1057-1066.

41. Matsuyama S., et al. "The inhaled corticosteroid ciclesonide blocks coronavirus RNA replication by targeting viral NSP15". bioRxiv (2020).

42. Hui Li., et al. "Effect of low-to-moderate-dose corticosteroids on mortality of hospitalized adolescents and adults with influenza A(H1N1)pdm09 viral pneumonia". Influenza Other Respir Viruses 11.4 (2017): 345-354.

43. Koichiro Kudo., et al. "Systemic Corticosteroids and Early Administration of Antiviral Agents for Pneumonia with Acute Wheezing due to influenza A(H1N1)pdm09 in Japan". PLoS One 7.2 (2012): e32280.

44. Awen Menou., et al. "Type II Transmembrane Serine Proteases”. Journal of Biological Chemistry 284.35 (2009): 2317723181. 
45. Nasef Abdelsalam and RezkAmer Mohamed Ibrahim. "Effects of methyl prednisolone in early ARDS". Egyptian Journal of Chest Diseases and Tuberculosis 62.1 (2013).

\section{Assets from publication with us}

- Prompt Acknowledgement after receiving the article

- Thorough Double blinded peer review

- Rapid Publication

- Issue of Publication Certificate

- High visibility of your Published work

Website: https://www.actascientific.com/

Submit Article: https://www.actascientific.com/submission.php Email us: editor@actascientific.com

Contact us: +919182824667 